\title{
Love is blind: partisan alignment and political corruption in Spain
}

\author{
Miguel Ángel Borrella-Mas ${ }^{1,2}$ (D) Martin Rode $^{1}$ (D)
}

Received: 7 September 2020 / Accepted: 9 February 2021 / Published online: 8 March 2021

(c) The Author(s) 2021

\begin{abstract}
Ever since the spectacular boom and bust cycle of the Spanish real estate industry, endemic corruption at the local level has become a widely recognized problem in the national public discourse. In an effort to expose an under-explored political determinant, this paper investigates the effect of local and regional alignment in fomenting corruption at the Spanish municipal level. To do so, we construct an ample panel dataset on the prevalence of corrupt practices by local politicians, which is employed to test the possible impact of partisan alignment in three consecutive joint municipal and regional elections. Findings show aligned municipalities to be more corrupt than non-aligned ones, an effect that is further associated with absolute majorities at both levels of government and higher capital transfers. By contrast, we also show that "throwing the rascals out" could be an effective strategy for curbing the corrupt practices of aligned municipalities. This indicates that the democratic political process may be effective in corruption control if agreements can be reached to remove corrupt politicians or parties from power.
\end{abstract}

\footnotetext{
We would like to thank Manuel Bagues, Christan Bjørnskov, Antonio Cabrales, M. Dolores Collado, Tommaso Nannicini, Salvatore Nunnari, Ignacio Ortuño-Ortiz, Nicola Persico, Ian Preston, Marcello Sartarelli, Francesco Turino, Marcos Vera, and three anonymous referees for helpful suggestions on earlier versions. Participants of the following meetings have further contributed with comments: the 2014 Petralia Sottana 1st Job Market Boot Camp, the XXXIX SAEe Simposio, the 2015 RES PhD meeting \& Job Market, the 6th AEDE Annual Conference, the 2015 ES European Winter Meeting, the ALdE XIX Applied Economics Meeting, the 2017 EPCS Annual Conference, and the XLIV SAEe Simposio. All remaining errors are naturally our own.
}

$凶 \quad$ Miguel Ángel Borrella-Mas

mborrella@unav.es

Martin Rode

martinrode@unav.es

1 Department of Economics, Universidad de Navarra, Edificio Amigos, 31009 Pamplona, Spain

2 Navarra Center for International Development, Universidad de Navarra, Edificio Amigos, 31009 Pamplona, Spain 
Keywords Corruption control - Elections · Partisan alignment - Political corruption . Spain

JEL Classification D72 $\cdot$ D73 $\cdot$ H77 $\cdot$ P16

\section{Introduction}

Political corruption and malfunctioning governments are a widespread phenomenon on a worldwide level. ${ }^{1}$ International organizations regularly highlight that the diversion of public funds for private benefit is probably one of the most important threats to the stability of many developed economies (Kaufmann et al. 2004, 2009), with estimations equating the overall cost to be more than 5\% of global GDP (OECD 2013), and increasing by about $10 \%$ the average cost of doing business (World Economic Forum 2008). Other studies have looked at the detrimental consequences for economic growth (Mendez and Sepulveda 2006), investment (Mauro 1995; Wei 2000), and international trade (de Jong and Bogmans 2011), to name only a few. ${ }^{2}$

Contrasting with the relatively well-documented economic outcomes, empirical evidence on the political determinants of corruption still presents many unknowns, according to surveys by Pellegrini and Gerlagh (2008) and Dimant and Tosato (2018). In particular, the role played by decentralization is regarded as uncertain, where some find federalism to be an important element in containing corruption (Dell'Anno and Teobaldelli 2015; Villalonga 2018), while others highlight the potential multiplication of corruption possibilities through decentralized administrations (Fisman and Gatti 2002; Gerring and Thacker 2004; Erlingsson et al. 2008; Fan et al. 2009; Albornoz and Cabrales 2013). Related to this, the frequent re-election of corrupt politicians also highlights the complex interplay of different incentives at work in national, regional, and local electoral processes, where punishment of corrupt incumbents is not always the default option (Miller 1999; Reed 1999; Manzetti and Wilson 2007; Ferraz and Finan 2008, 2011; Jiménez et al. 2013). Similar evidence has also been found at the Spanish local level by Costas-Pérez et al. (2012), Jiménez and García (2018), or Fernández-Vázquez et al. (2016), where the effects of news coverage, political ideology, and income seem to play crucial roles for electoral decisions. ${ }^{3}$

Following this literature, uncovering the political determinants of corruption is key to understanding the role that institutions play in its emergence. In this paper, we examine whether ruling a regional and local government at the same time, henceforth partisan alignment, has an impact on political corruption among local governments in

\footnotetext{
${ }^{1}$ It is important to distinguish between political and bureaucratic corruption (Amundsen 1999). The latter solely arises from unlawful behavior by bureaucrats in the public administration. The former may arise likewise, and in addition, when legislation is tailored to benefit politicians. See Fitzpatrick (2007) for a comprehensive definition.

${ }^{2}$ See Perspectives (1998) for a detailed description of the pervasive impact of corruption.

${ }^{3}$ In turn, consensus on the negative impact of corruption for public confidence in democratic systems and political trust seems to be substantial (Anderson and Tverdova 2003; Bowler and Karp 2004; Warren 2004; Solé-Ollé and Sorribas-Navarro 2018; Sanz et al. 2020).
} 
Spain. To the best of our knowledge, this possibility has not been considered to date in the relevant literature, and our paper is the first to do so empirically.

Theoretically, alignment could impact corruption in several different ways: On the one hand, alignment may induce corruption, and several overlapping mechanisms could be at work. First, a variety of studies have already shown that aligned municipalities benefit from more favorable budgetary decisions taken at a higher government level for countries as diverse as Albania (Case 2001), Brazil (Brollo and Nannicini 2012), France (Fabre 2014), India (Arulampalam et al. 2009; Dey and Sen 2016), Italy (Bracco et al. 2015; Carozzi and Repetto 2016), Portugal (Migueis 2013), Spain (Solé-Ollé and Sorribas-Navarro 2008; Curto-Grau et al. 2018), and the United States (Levitt and Snyder Jr 1995; Larcinese et al. 2006). According to this literature, the possibility of corruption could increase with the number of public programs that are being implemented at the local level, a possibility which is even higher for aligned municipalities. Seen from this point of view, public sector corruption is simply a function of the available transfers that can be diverted (Holcombe 2013). Second, and following a very similar logic, aligned municipalities may be better able to "afford" to be corrupted. That is, any negative effects from corruption for local public finances would be compensated for by the comparatively higher transfers from aligned regional governments.

Third, if local politicians benefit from better connections via alignment when obtaining public contracts and projects with firms, private sector-related corruption possibilities could be more abundant for politicians of aligned municipalities (cf. Gutmann and Lucas 2018). Finally, a lack of monitoring from upper-tier governments and a tendency to turn a blind eye toward corruption when the same party controls both levels may create incentives for local politicians to seize corruption opportunities more readily when they are available. Essentially, corruption here constitutes a potential alternative for regional administrations to reward aligned (and loyal) local governments.

On the other hand, the effect of partisan alignment on local level corruption could be negative, if regional governments are better able to influence aligned municipalities to behave according to the law by more credibly threatening them, an influence which cannot be exercised in the case of non-aligned municipalities. For example, via the threat of removing party support, forcing corrupt politicians to resign from office or leave the party, etc. Finally, there may be no association at all with regard to monitoring if regional governments behave similarly toward aligned and non-aligned local governments.

In the following, we investigate the important question of whether partisan alignment impacts corruption at the local level, constructing a dataset on corrupt practices from press news published over a period of 15 years, matching it with local and regional electoral data over three consecutive electoral cycles between 1999 and 2011. Findings show that aligned municipalities are significantly more associated with corruption than non-aligned ones. The association is stronger where regional governments enjoy an absolute majority, and in municipalities receiving higher capital transfers from regional governments, which is very much in line with previous studies on the allocation of transfers to aligned municipalities in Spain (Solé-Ollé and Sorribas-Navarro 2008; Curto-Grau et al. 2018). By contrast, we find that "throwing the rascals out" 
may be an effective strategy for curbing the corrupt practices of aligned municipalities when allegedly corrupt mayors or parties are actually removed from power. In the tradition of Olson (1982), this actually suggests that a certain level of political instability is desirable, potentially making it more difficult for corrupt politicians to completely dominate a local political system. Finally, findings are robust to the inclusion of additional controls, several estimation methods, different definitions of alignment, and also to falsification tests.

The remainder of the paper is organized as follows: Sect. 2 outlines the relevant institutional setting in which Spanish local and regional elections take place. Section 3 describes our data and the research design in detail, while Sect. 4 presents the results. Finally, Sect. 5 discusses the results and concludes.

\section{Institutional setting}

Spain is a parliamentary democracy with three elected levels of government: central, regional, and local. Geographically, the territory is divided into 17 regions and more than 8000 municipalities. ${ }^{4}$ About $84 \%$ of all municipalities have fewer than 5000 inhabitants, accounting for roughly just $15 \%$ of the entire population.

In Spanish federalism, regional governments are in charge of important spending responsibilities, such as public education, health care, and social welfare more generally, including important transfers to the local level. On the local level, responsibilities increase with population size, which is recognized in the form of higher per capita transfers for larger municipalities and a greater tax autonomy. Generally, municipalities are in charge of providing basic services such as public transport, civil protection, environmental services, and urban development. The latter was strongly associated with most local level corruption in Spain during the real estate boom of the 1990s and 2000s (Costas-Pérez et al. 2012). The funding of urban development expenditure depends heavily on discretionary grants provided by upper-tier government levels, which represents an overall one third of total local revenues. ${ }^{5}$ The other two thirds are self-financed by municipal revenues, mainly stemming from local taxes.

Politically, Spanish municipalities are ruled by an indirectly elected mayor (alcalde) and a directly elected city council (ayuntamiento). ${ }^{6}$ For the latter, closed list elections are held simultaneously in all of the country's municipalities, with more than a total of 66000 local representatives proportionally elected every four years. Interestingly, most regional elections (13 out of 17) are held the same day, with only four historically determined regions constituting important exceptions to this rule. Especially in some of these linguistic minority regions, regional parties have also played key roles in local politics. However, from the early 1990s to around 2015, two national level parties were

\footnotetext{
4 There is also an intermediate upper-local layer for purely administrative purposes, called the Diputación, in those regions with more than one province-an important exception to this rule are the Canary Islands.

5 As an illustrative example, municipalities received capital transfers from the central (10\%), regional (almost 50\%), and upper-local (almost 25\%) governments in 2004. Source: http://www.minhafp.gob.es/ es-ES/CDI/Paginas/SistemasFinanciacionDeuda/InformacionEELLs/HaciendasLocalesencifras.aspx (last access: March 3, 2021).

${ }^{6}$ See (AA.PP. 2008) for a complete report of the Spanish local government system.
} 
predominant in most local political systems: the social-democratic Spanish Socialist Workers' Party (PSOE), and the Christian-conservative People's Party (PP).

Electing mayors may require coalitions by two or more parties, but only about one third of the municipalities under observation in our data were ruled by a party without an absolute majority. Additionally, local coalitions are also formed along ideological lines in most cases (Curto-Grau et al. 2018). ${ }^{7}$ City councils constitute a small representative democracy with majority voting, where mayors act as the highest representative authority, responsible for local government and administration. Nevertheless, mayors can be removed through a no-confidence vote (moción de censura), if another candidate has the majority support of the council. Given the closed-list electoral system, parties are highly disciplined, giving mayors a large degree of discretionary power, especially when parties enjoy an absolute majority. In addition, citizens do not have relevant ways of participating in the council decisions, and the degree of transparency in each municipality depends heavily on the judgments of local representatives.

In fact, the institutional reaction to the surge in local corruption shows quite well how difficult it is to exercise effective political and judicial control. Before the Spanish real estate bubble burst in 2008 this topic was hardly on the agenda at all. Individual journalists and certain media outlets deserve credit for systematically exposing it initially, which probably also drove the electoral reaction of many citizens (CostasPérez et al. 2012), for whom corruption became an increasing concern sometime after 2011. It took years for political parties and the judicial system to react effectively to these allegations though, substantially contributing to the current revolution of the Spanish party system at a time when many judicial processes linked to corruption scandals in this dataset are effectively still ongoing.

\section{Data and empirical strategy}

\subsection{Data}

Empirical corruption research always faces the problem of obtaining data on activities that are, for the most part, also considered formally illegal. In this paper, we circumvent this limitation by constructing a dataset containing news media information on corrupt practices at the Spanish municipal level between 1999 and 2011. In particular, we codify two corruption studies, each carried out by one of the main newspapers in the country, namely the left-wing El Pais and the right-wing El Mundo for three consecutive local elections in 1999, 2003, and 2007. ${ }^{8}$ We further follow the approach by Saiz and Simonsohn (2013), employing internet-guided searches to complete the database.

Generally speaking, the objective is to identify municipalities in which local politicians were involved in scandals relating to fraud, misuse of public funds, bribery, etc. Knack (2006) has effectively referred to this type of corruption as "state capture," dis-

\footnotetext{
7 If no candidate is elected by absolute majority in the first round, the first list-placed representative whose party obtained the most votes in the election is appointed as mayor.

${ }^{8}$ Both studies provide very similar information. See Alternativas (2007) and El Mundo (2006) for more details. See also Jerez Darias et al. (2012) for a geographical description of local corruption scandals.
} 
tinguishing it from petty corruption. In the following, we checked on a case-by-case basis to identify the electoral period during which the corruption scandal appearing in the media had actually occurred, irrespective of the point in time when citizens had access to information on these practices. The corresponding outcome variable is then simply defined as a dummy that is equal to 1 , if we observe a corruption case for a certain municipality during a specific electoral period, and 0 otherwise. The exact definition of corruption employed, and a more extensive description about the resulting data is found in Appendix A of ESM.

In order to estimate the effect of partisan alignment on corruption, we match the information on corruption with municipality-level panel data, employing three different sources of information: First, results for the three consecutive local elections in 1999, 2003, and 2007, provided by the Spanish Interior Ministry. ${ }^{9}$ With this information, we calculate vote shares obtained by the incumbent mayor's party for each municipality and several dummies capturing whether (i) the ruling party enjoyed an absolute majority, (ii) the incumbent was re-elected, and whether (iii) there was a change in the local government during the electoral period. ${ }^{10}$ Furthermore, we collected data on mayors' individual characteristics, namely gender, age, education, and experience in office. Finally, corresponding data for all regional elections was directly collected from each regional government. Consequently, the main variable of interest "partisan alignment" is a dummy equal to 1 , if the same party controls the local council and the regional government for an electoral period, and 0 otherwise. ${ }^{11}$

Second, we collect budgetary data for each municipality from the yearly local budget survey conducted by the Spanish Ministry of Finance. ${ }^{12}$ This survey contains detailed information on sources of local income and expenditures programs. Specifically, we introduce per capita measures of direct and indirect taxes, current- and capital transfers from other government layers, and property income. ${ }^{13}$

Third, socioeconomic and demographic characteristics for a wide range of municipalities are obtained from La Caixa, in order to control for additional municipal characteristics that are likely to be correlated with corrupt practices. ${ }^{14}$ This set includes: unemployment, population growth, the number of savings banks, and the total number of small businesses in the municipality. Given the lack of these data for smaller communities, we had to restrict the sample employed in the empirical analysis to municipalities above 1000 inhabitants, giving us a final sample of 9733 total observations for the years 1999-2011.

\footnotetext{
9 Source: http://www.infoelectoral.mir.es/min/home.html (last access: March 3, 2021).

10 The latter may happen due to a change of mayor within the same party, or also because of a change in the party ruling the municipality.

11 In addition, we also define "coalition alignment," a broader definition of alignment being equal to 1, if a party ruling a municipality is also in a coalition running the corresponding regional government, independent of its position within that coalition. We show in Appendix B.3 of ESM that our results prove robust to this broader definition of alignment.

12 Source: http://serviciostelematicosext.minhap.gob.es/SGCAL/entidadeslocales/.

13 Variables are computed dividing the average for the four years in each electoral cycle over the total population at the beginning of each electoral period. In all cases, we consider the electoral year as the last year of the cycle.

14 Source: Economic Yearbook of Spain - http://www.anuarioeco.lacaixa.comunicacions.com.
} 
Table 1 shows summary statistics for all variables employed in the empirical analysis, further separating means for aligned and non-aligned municipalities. For both groups, $P$ values indicate whether differences of subgroups are statistically significant. Overall, aligned municipalities tend to be more corrupt and more concentrated in $P P$ or PSOE hands. In addition, these same local governments seem to be politically more stable, meaning that there is a higher probability of incumbents' being re-elected, and a lower probability of the ruling party being ousted during an electoral term.

Figure 1 shows the geographical distribution of our 561 Spanish municipalities affected by corruption for the period from July 1999 to May 2011, distinguishing between aligned and non-aligned cases by color. Each dot represents a municipality with one or more corruptions cases, with the size of dots visually illustrating the number of total cases by municipality. Of these, 452 municipalities experienced just one corruption case, 82 in the first electoral period, 234 in the second, and 136 in the third. A total of 96 municipalities experienced a corruption case in two different electoral cycles, and 13 in all three electoral cycles considered. ${ }^{15}$

The concentration of cases in the second and third electoral period shows just how much municipal corruption in Spain is linked to the real-estate boom of the early to mid 2000's, which came to an abrupt end around 2008. Furthermore, the map also makes clear how corruption cases are more concentrated along the Mediterranean coast, the South, in the areas around Madrid, and, to a somewhat lesser extent, in the north-western region of Galicia. Most importantly for our estimation strategy, alignment seems to matter for corruption, but the territorial distribution of aligned cases is clearly similar to that of non-aligned ones.

\subsection{Empirical strategy}

The outcome variable Corr $_{\text {irt }}$ is defined as a dummy that is equal to 1 , if municipality $i$ presented a corruption case in region $r$ and period $t$. Similarly, the treatment of interest, partisan alignment, is equal to 1 when the same party controls both the local city council and the regional government. The objective is to identify the effect of treatment (alignment) on the prevalence of municipal corruption. However, corruption cannot be simultaneously observed in the event that the municipality is aligned, and in the counterfactual event in which it is not, leading to the fundamental problem of causal inference.

In the following, we let dummy $A_{\text {irt }}$ be equal to 1 for treated municipalities, 0 otherwise. The effect is then estimated as the difference in the mean probability of corruption between municipalities that are aligned $\left(A_{i r t}=1\right)$ and those that are not $\left(A_{\text {irt }}=0\right)$, using the following model:

$$
\operatorname{Corr}_{i r t}=\alpha_{i}+\gamma_{t}+\gamma_{t} * \theta_{r}+\beta A_{i r t}+X_{i r t}^{\prime} \delta+\epsilon_{i r t}
$$

where the error term $\epsilon_{i r t}$ is clustered at the local level. Equation (1) provides information on the impact of partisan alignment on political corruption, independent of the party ruling the municipality and the date when the scandal appeared in the media. The

\footnotetext{
$\overline{15}$ Note that the map excludes 29 cases in the Canary Islands for optical reasons.
} 
Table 1 Summary statistics by partisan alignment

\begin{tabular}{|c|c|c|c|c|}
\hline & $\begin{array}{l}\text { (1) } \\
\text { All }\end{array}$ & $\begin{array}{l}(2) \\
\text { Partisan } \\
\text { alignment }\end{array}$ & (3) & (4) \\
\hline & & Yes & No & $P$ value \\
\hline \multicolumn{5}{|l|}{ Outcome variable } \\
\hline Corruption & 0.070 & 0.082 & 0.057 & 0.000 \\
\hline \multicolumn{5}{|l|}{ Electoral variables (local) } \\
\hline Participation rate & 0.743 & 0.745 & 0.739 & 0.002 \\
\hline Vote share current incumbent & 0.483 & 0.508 & 0.455 & 0.000 \\
\hline $\mathrm{PP}$ in power (local) & 0.311 & 0.360 & 0.256 & 0.000 \\
\hline PSOE in power (local) & 0.417 & 0.533 & 0.288 & 0.000 \\
\hline PP or PSOE in power (local) & 0.728 & 0.893 & 0.544 & 0.000 \\
\hline Other party in power (local) & 0.080 & 0.000 & 0.168 & 0.000 \\
\hline$=1$ if mayor's change (different party) & 0.061 & 0.041 & 0.082 & 0.000 \\
\hline$=1$ if mayor's change (same party) & 0.115 & 0.103 & 0.128 & 0.000 \\
\hline$=1$ if incumbent re-elected & 0.533 & 0.578 & 0.483 & 0.000 \\
\hline$=1$ if absolute majority at local level & 0.644 & 0.734 & 0.544 & 0.000 \\
\hline \multicolumn{5}{|l|}{ Mayors' characteristics } \\
\hline$=1$ if female & 0.122 & 0.125 & 0.119 & 0.349 \\
\hline Mayor's age & 47.280 & 47.351 & 47.200 & 0.440 \\
\hline Mayor's education & 5.449 & 5.421 & 5.480 & 0.141 \\
\hline$=1$ if superior education & 0.421 & 0.419 & 0.423 & 0.647 \\
\hline Mayor's number of terms in office & 2.210 & 2.269 & 2.145 & 0.000 \\
\hline$=1$ if above median terms & 0.579 & 0.595 & 0.560 & 0.000 \\
\hline \multicolumn{5}{|l|}{ Electoral variables (regional) } \\
\hline $\mathrm{PP}$ in power (regional) & 0.353 & 0.360 & 0.346 & 0.131 \\
\hline PSOE in power (regional) & 0.533 & 0.533 & 0.533 & 0.987 \\
\hline PP-PSOE in power (regional) & 0.886 & 0.893 & 0.879 & 0.025 \\
\hline Other party in power (regional) & 0.114 & 0.107 & 0.121 & 0.025 \\
\hline$=1$ if absolute majority at regional level & 0.587 & 0.663 & 0.504 & 0.000 \\
\hline$=1$ if concurrent elections & 0.549 & 0.565 & 0.532 & 0.001 \\
\hline \multicolumn{5}{|l|}{ Income variables (Euro per capita) } \\
\hline Direct taxes & 299.739 & 335.151 & 259.531 & 0.481 \\
\hline Indirect taxes & 60.004 & 67.250 & 51.777 & 0.451 \\
\hline Current transfers & 323.624 & 349.549 & 294.188 & 0.316 \\
\hline Property income & 31.689 & 36.669 & 26.034 & 0.251 \\
\hline Capital transfers & 181.081 & 199.523 & 160.141 & 0.001 \\
\hline
\end{tabular}


Table 1 continued

\begin{tabular}{lllll}
\hline & $\begin{array}{l}(1) \\
\text { All }\end{array}$ & $\begin{array}{l}(2) \\
\text { Partisan } \\
\text { alignment }\end{array}$ & $(3)$ & $(4)$ \\
& & Yes & No & $P$ value \\
\hline Baseline characteristics & & & & \\
$=1$ if 1999 electoral cycle & 0.335 & 0.351 & 0.318 & 0.000 \\
$=1$ if 2003 electoral cycle & 0.330 & 0.315 & 0.347 & 0.001 \\
$=1$ if 2007 electoral cycle & 0.335 & 0.334 & 0.335 & 0.904 \\
Population (log) & 8.350 & 8.354 & 8.346 & 0.754 \\
Population gr. rate & -0.038 & -0.033 & -0.043 & 0.000 \\
Unemployment & 0.064 & 0.066 & 0.062 & 0.000 \\
Unemployment gr. rate & -0.188 & -0.186 & -0.190 & 0.580 \\
Number of saving banks & 6.465 & 7.252 & 5.574 & 0.040 \\
Number of small business & 283.364 & 306.042 & 257.750 & 0.092 \\
N. Observations & 9733 & 5114 & 4619 & \\
\hline
\end{tabular}

Column (1): Means for all municipalities. Columns (2-3): Means for aligned and non-aligned municipalities. Column (4): $P$ values for the null hypothesis that differences in means are equal to zero

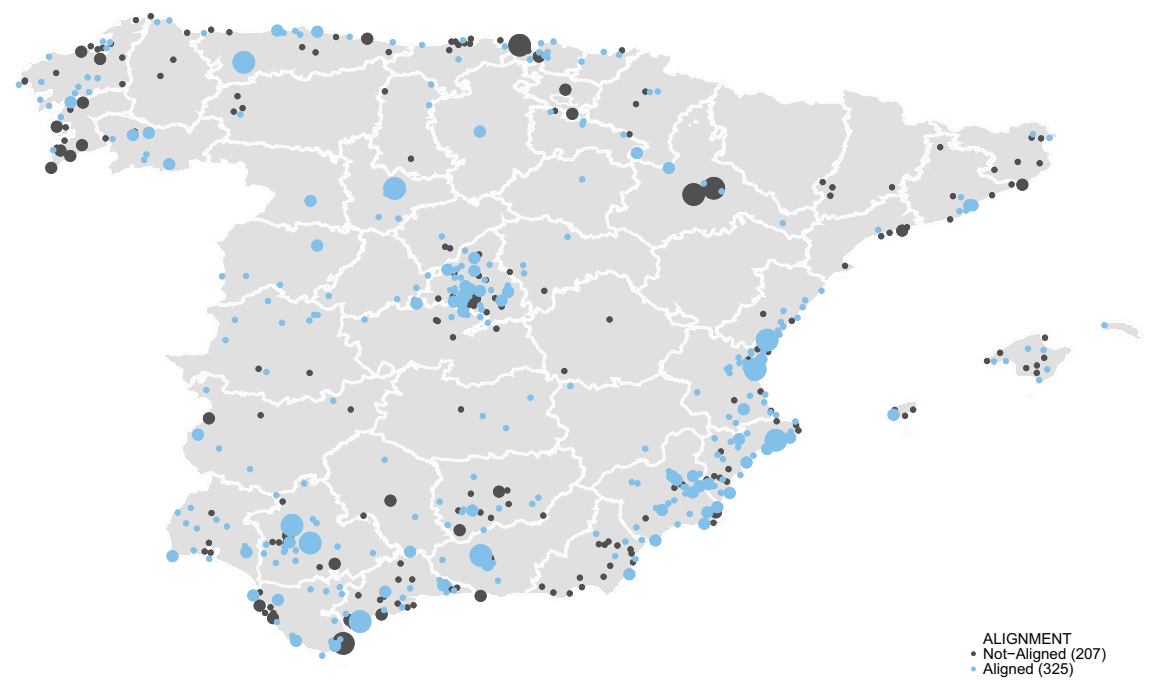

Note: Small dots $=$ one case. Medium dots $=$ two cases. Large dots $=$ three cases.

Fig. 1 Local corruption cases by alignment. Note Small dots $=$ one case. Medium dots $=$ two cases. Large dots $=$ three cases 
parameter of interest in this equation is $\beta$, which captures the change in the probability of observing corruption that is due to partisan alignment, holding other factors fixed. ${ }^{16}$ In this equation, $\alpha_{i}$ and $\gamma_{t}$ are municipality and electoral term fixed effects, controlling for (i) any time-invariant characteristic that may have an influence both on corruption and the alignment status of municipalities and (ii) the growth of corruption common to all municipalities. In addition, we further include the term $\gamma_{t} * \theta_{r}$, to account for the possibility that changes in political support within regions could be correlated with changes in corruption in that same region's municipalities. Finally, $X_{i t}$ is a vector of controls variables, all described and summarized in Table 1 of the previous subsection.

If alignment preferences are a decisive factor for determining the outcome of municipal elections, this estimation strategy would be subject to reverse causality. On the margin, we do not consider this to be the case, relying on the following reasoning: First, the high degree of overall uncertainty in a mostly parallel electoral process. Since most regional and local elections are held the same day, two specific results have to coincide for a certain alignment outcome to materialize. ${ }^{17}$ Second, the general behavior of voters, which is seldom guided by rational or strategic considerations of the kind, but seems rather to be driven by expressive behavior (Caplan 2011). Third, and coinciding with these two arguments, the specific behavior of Spanish voters, who traditionally reward their ideologically most preferred party in regional elections, while voting for the platform of the most highly valued politician in local elections, even if these two do not coincide in ideological terms (Sanz Cazorla 2007; Delgado 2010).

Obviously, this strategy cannot fully exclude the possibility that the election of an aligned (or a non-aligned) local leader is driven by some external time-variant factor that also affects the possibility of observing corruption. Even if voters do not care about alignment at all, alignment may be correlated with some other unknown variable that could in turn affect corruption, which we cannot fully control for in our empirical model. Notwithstanding, our estimation strategy implies that alignment is conditionally mean independent of the unobserved term after including all the control variables, and many of the robustness checks presented in Appendix B of ESM are conducted to exclude related endogeneity issues as much as possible. In a nutshell, while we consider reverse causality to be an unlikely driver of the findings, it is impossible to fully exclude endogeneity concerns in our framework, although we find no indications that such issues severely bias our baseline results in a significant way.

In order to shed some light regarding the circumstances under which corruption is more likely to occur, we further assess whether the intensity of local political corruption depends on a series of heterogeneous effects, namely: the logarithm of per capita capital transfers to the municipality, absolute majorities at the local and regional level, or changes in local governments between electoral periods, where $\tau$ denotes the cor-

\footnotetext{
16 We choose to estimate a linear probability model instead of probit or logit models for several reasons. First, it is not convenient to use a probit model with fixed effects and small $\mathrm{T}$, due to the incidental parameters problem (Greene 2004). Second, the assumptions needed to estimate a logit model with fixed effects are unlikely to hold and, in addition, they do not provide marginal effects. Third, using an LPM is a suitable alternative given that the main purpose is to estimate the average causal effect, and not to predict it.

17 Note that the latter does not include other overlapping (ideological) preferences that might indirectly influence alignment results, which are in turn driven by external events, such as an economic crisis. The latter would be quasi-random for the purpose of its impact on corruption, when employing election and municipality fixed effects, as we do here.
} 
responding variable in our estimated equation.

$$
\operatorname{Corr}_{i r t}=\alpha_{i}+\gamma_{t}+\gamma_{t} * \theta_{r}+\beta_{0} A_{i r t}+\beta_{1} \tau_{i r t}+\beta_{2} \tau_{i r t} * A_{i r t}+X_{i r t}^{\prime} \delta+\epsilon_{i r t}
$$

In Eq. (2), the coefficient $\beta_{0}$ now captures the effect of partisan alignment for the subgroup of municipalities (i) receiving lower capital transfers per inhabitant, (ii) without absolute majorities (local or regional), or (iii) politically stable municipalities, respectively. Correspondingly, $\beta_{1}$ captures the change in the probability of being corrupt that is due to (i) higher capital transfers per inhabitant, (ii) enjoying absolute majorities, or (iii) local political instability. Finally, $\beta_{2}$ measures the difference in the effect of partisan alignment between the subgroups of municipalities (i) with higher/lower capital transfers, (ii) with and without absolute majorities, or (iii) with and without a change in local government during the course of an electoral period. ${ }^{18}$

An important concern is that some of these characteristics could further be correlated with the alignment treatment. For example, given the evidence that alignment might cause a higher level of capital transfers (e.g., Solé-Ollé and Sorribas-Navarro 2008), identification is not clear in this case. Similarly, alignment and absolute majority status are jointly determined in elections, and aligned municipalities are also much more likely to present an absolute majority than non-aligned ones. As a consequence, these heterogeneous effects cannot be clearly identified and should rather be taken as indicative. Nonetheless, we consider them to be important for highlighting the circumstances under which Spanish municipal corruption is more (or less) likely to occur, despite not being able to make any definite causal claims here.

\section{Results}

\subsection{Main findings}

Table 2 shows estimates from Eq. (1), modifying the number of controls as we move from columns (1) to (6). Column (1) only includes the treatment variable and municipality fixed effects (FE), finding that partisan alignment significantly increases the probability of a corruption case occurring by about 2 percentage points. Taking into account that the mean level of corruption is $5.7 \%$ for non-aligned municipalities, this is a notable difference. Column (2) adds electoral cycle FE, while the specification with municipality, electoral, and electoral $+\times$ region $_{r} \mathrm{FE}$ is presented in column (3). Columns (4) to (6) repeat specifications from (1) to (3), further including all controls described in Sect. 3.2, confirming our previous finding. Focusing on the most complete specification in the last column, estimates represent a $29.82 \%$ increase in corruption for aligned municipalities, with respect to non-aligned ones.

\footnotetext{
18 We provide two addition tests in the empirical analysis. First, we test the effect on corruption of aligned municipalities with (i) higher capital transfers per inhabitant, (ii) enjoying absolute majorities, or (iii) local political instability $\left(\beta_{1}+\beta_{2}=0\right)$. Second, we also test the effect on corruption of being aligned for municipalities with (i) higher capital transfers per inhabitant, (ii) enjoying absolute majorities, or (iii) local political instability $\left(\beta_{0}+\beta_{2}=0\right)$.
} 


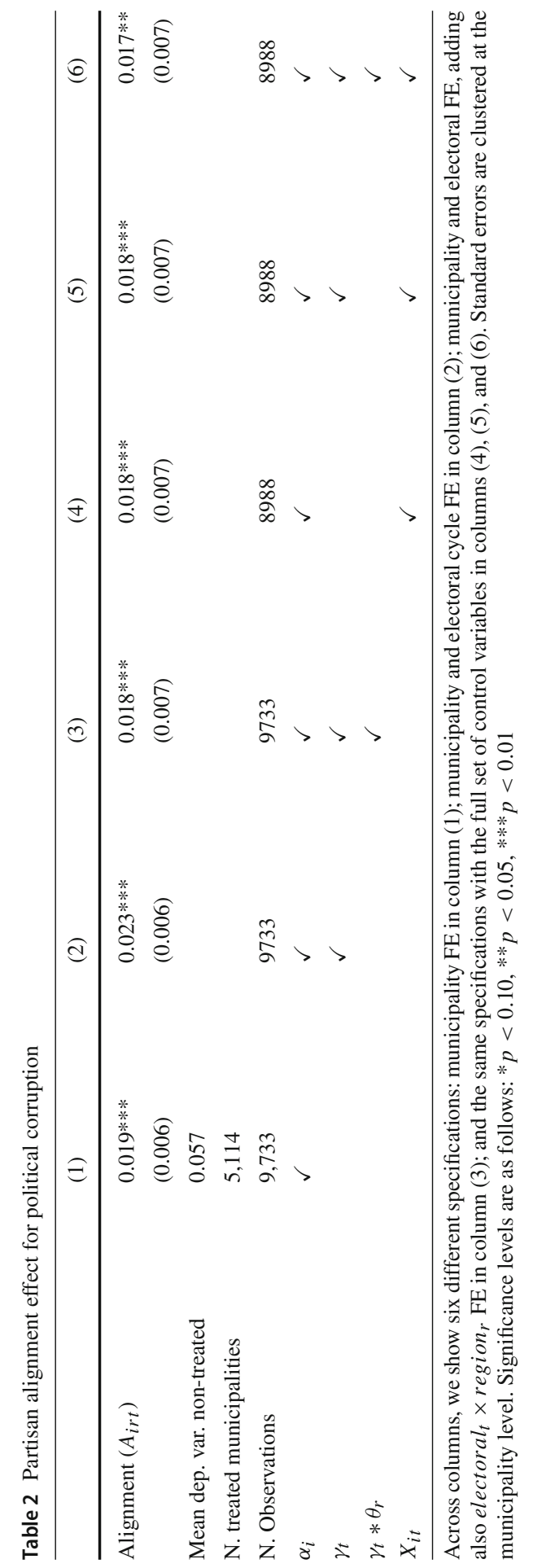


According to these results, partisan alignment seems to create important incentives for local governments to engage in political corruption. We can only speculate on the underlying political mechanisms, but it is rather likely that these are similar to those highlighted in the literature on alignment and transfers. Here, local politicians often benefit from better connections (Curto-Grau et al. 2018), which could potentially lead to a lack of monitoring from regional governments. Of course, in this case we are implicitly assuming that regional administrations have, at least in principle, an interest in curbing local level corruption. This might not necessarily be the case. Previous results from the alignment-transfers literature also suggest a non-negligible amount of coordination effort in allocating extra transfers to aligned municipalities (Solé-Ollé and Sorribas-Navarro 2008).

In an effort to uncover some of the mechanisms that create incentives for corruption at the municipal level, we further study a series of heterogeneous effects based on Eq. (2). First, Table 3 shows the association of partisan alignment with local political corruption depending on the level of capital transfers. Columns (1) to (6) repeat different models from Table 2. Top panel A shows results when calculating (per capita) capital transfers on the basis of the mean value for the whole electoral period, and bottom panel B only for the last two years. Marginal effects for the interaction term are also shown.

We find solid indications that aligned municipalities with higher capital transfers are significantly more corrupt, pointing in the direction of individual politicians potentially taking advantage of the connections created by political alignment. Moreover, the effect is stronger when using capital transfers calculated as the mean value over the last two years of the electoral cycle, which is consistent with the idea that these types of discretionary transfers take on more importance just before the next local elections. ${ }^{19}$

Second, Table 4 highlights the association of partisan alignment with local political corruption for absolute majorities, where columns (1) to (6) again repeat the different models. Here, top panel A shows results for absolute majorities on the local level, while bottom panel $\mathrm{B}$ for absolute majorities on the regional level, each with the corresponding marginal effects.

In both cases, we find solid indications that absolute majorities play a significant role in political corruption of aligned municipalities. Notwithstanding, on a purely numerical level, absolute majorities at the local level (panel A) seem to play a somewhat less important role than absolute majorities at the regional level (panel B). ${ }^{20}$ This would offer some support to our speculation on the specific importance of monitoring from regional administrations in curbing local level corruption. If there is no coalition party in a regional government to contend with, incentives to curtail such practices in politically aligned municipalities are substantially reduced.

\footnotetext{
19 Notice that receiving more capital transfers under alignment only matter for corruption when focusing on the last two years of the electoral cycle, as indicated by the test $\beta_{1}+\beta_{2}=0$ in both panels. By contrast, the effect of being aligned for municipalities receiving more capital transfers $\left(\beta_{0}+\beta_{2}\right)$ is similar in both panels.

20 Notice that both the effect of having absolute majorities under alignment $\left(\beta_{1}+\beta_{2}=0\right)$ and the effect of being aligned under absolute majorities $\left(\beta_{0}+\beta_{2}=0\right)$ yield similar results, although again the effects are somewhat stronger (in size) for the case of regional absolute majority.
} 


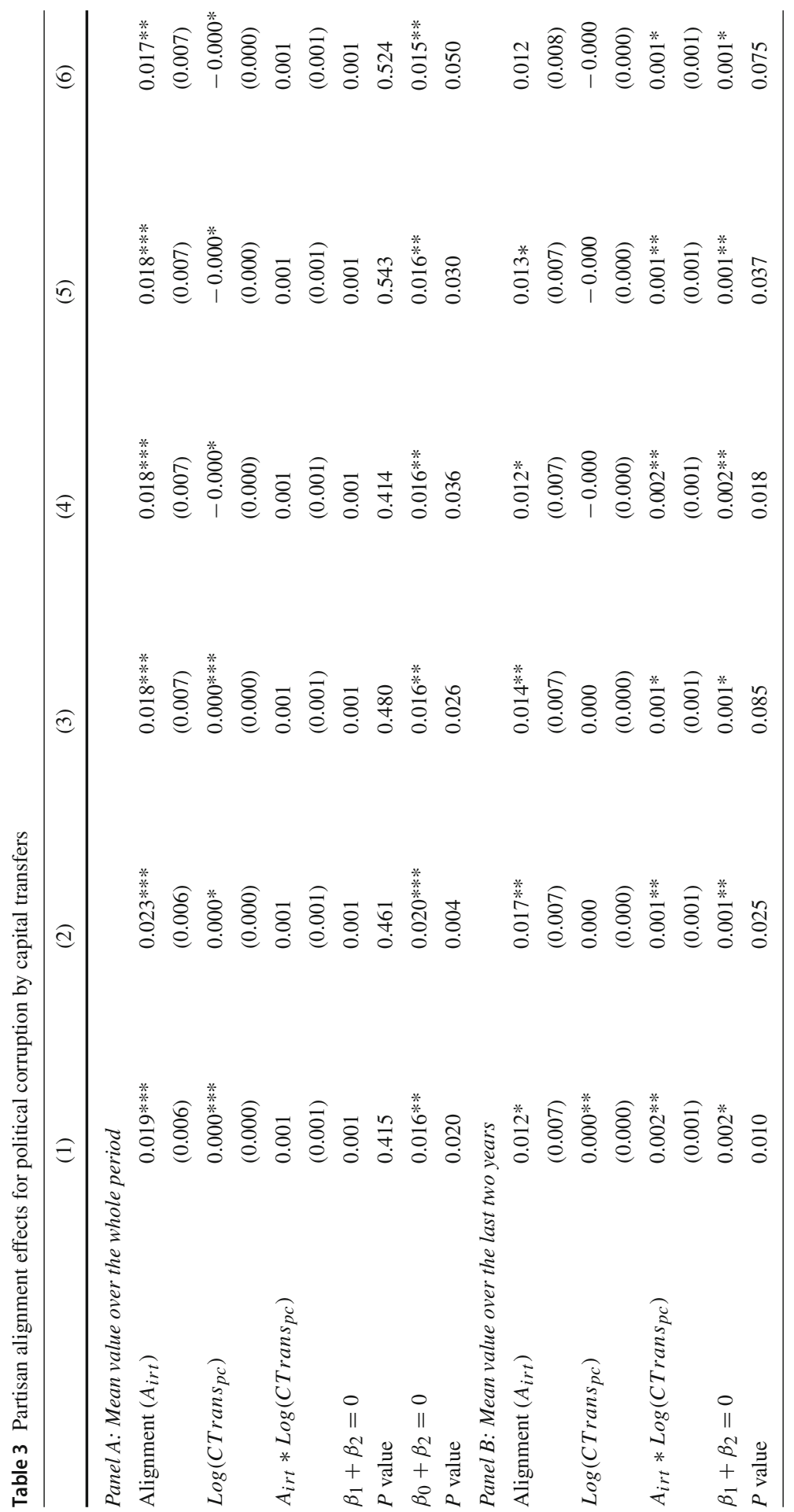




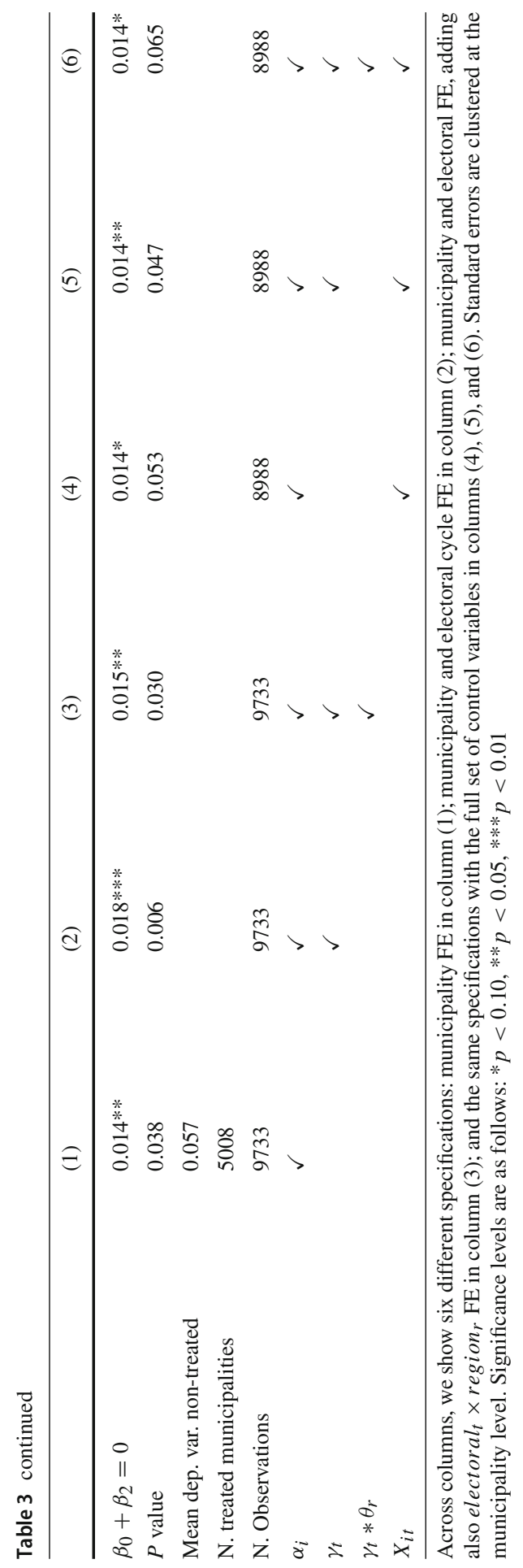




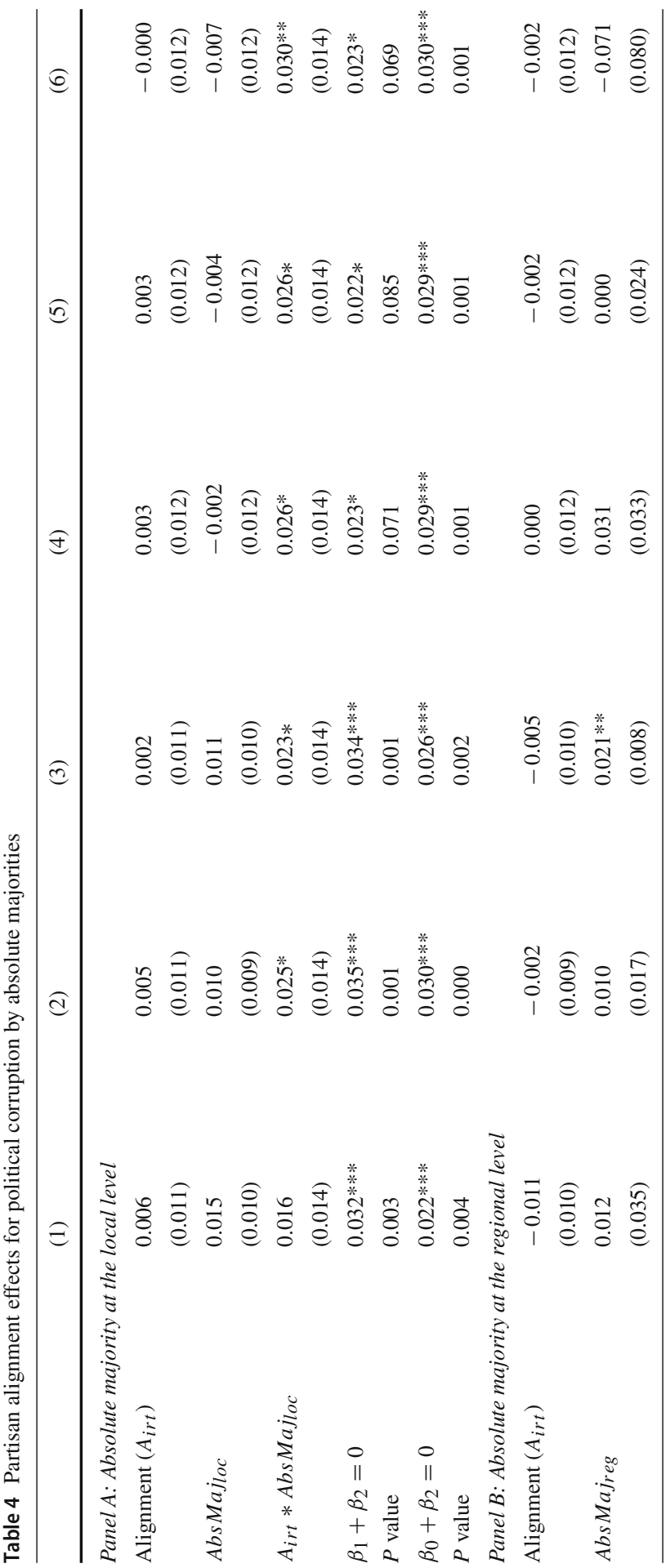




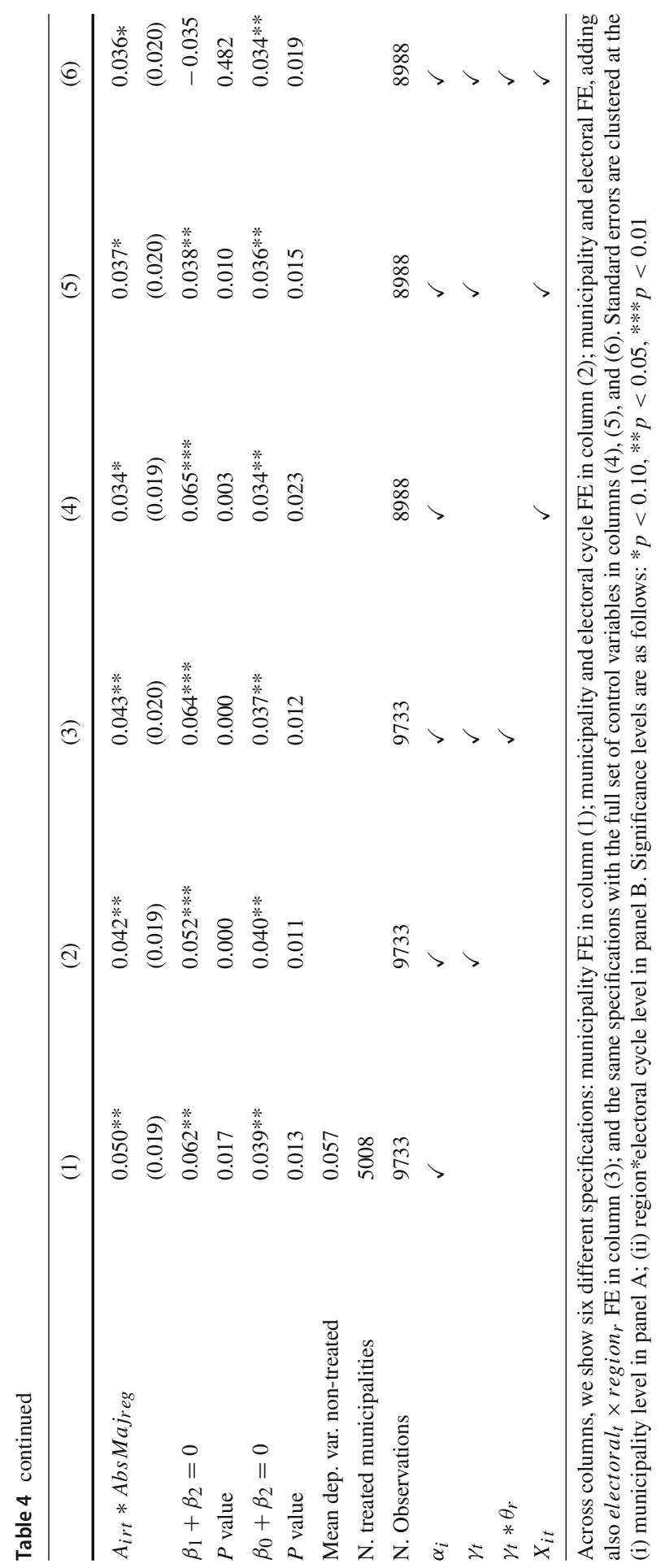




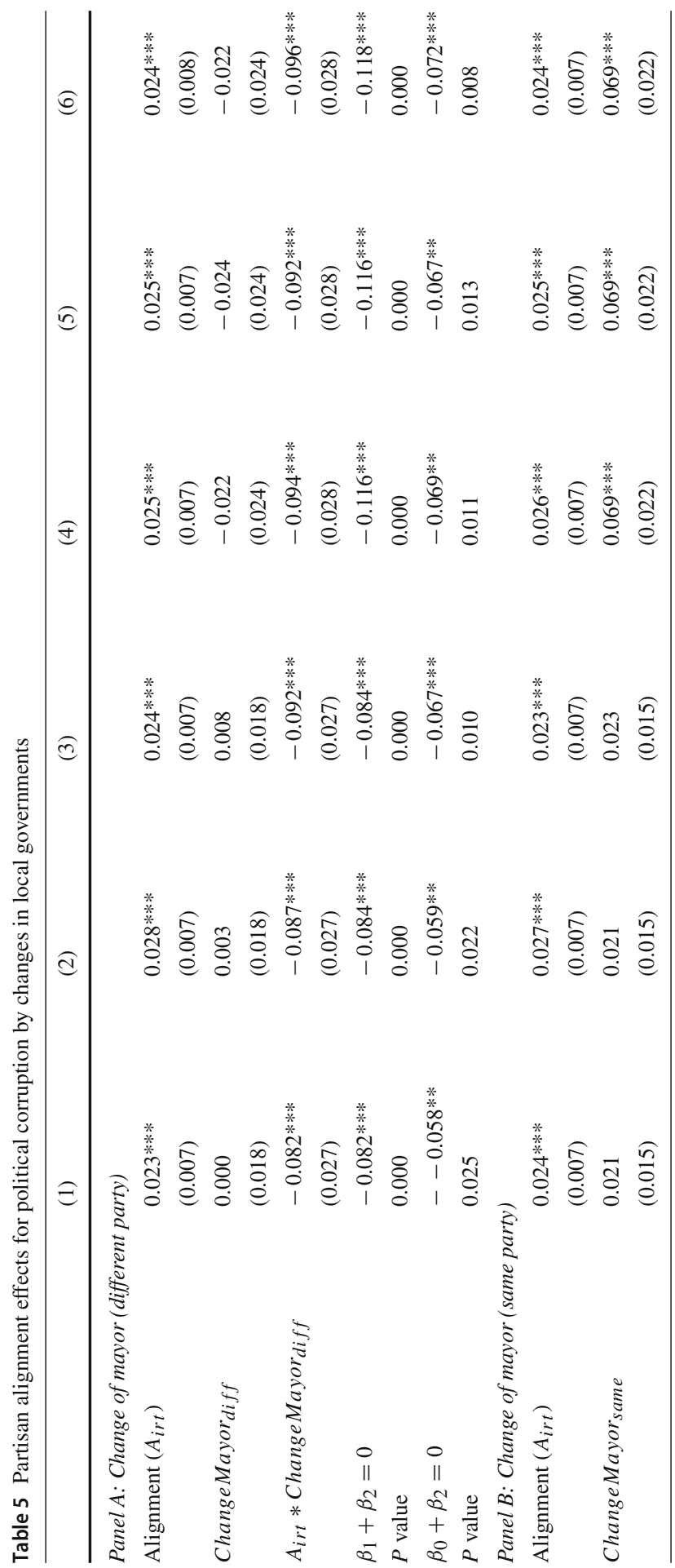




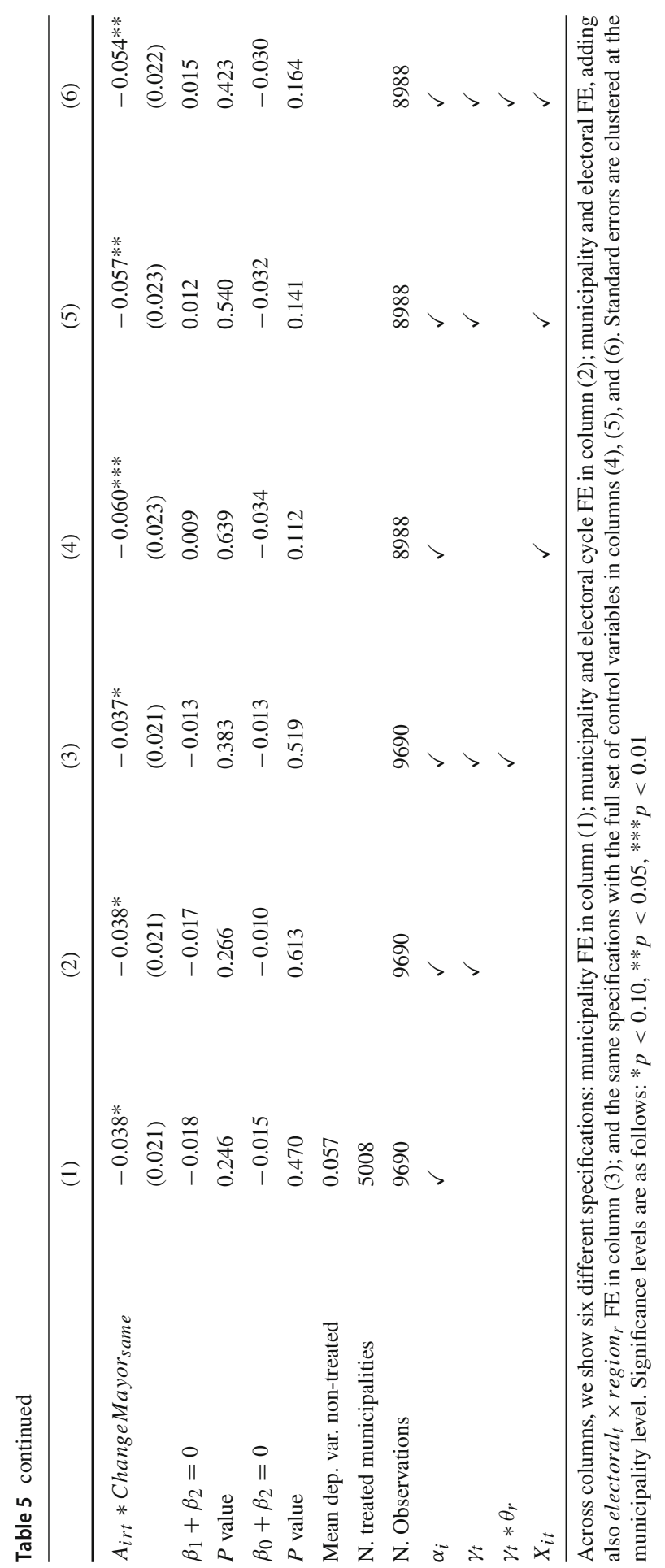


Third, in Table 5 we assess the association of partisan alignment with local political corruption, dependent on the municipal level of political stability. Top panel A shows results for a change in mayors during an electoral term, where the new mayor is from a different party. In turn, bottom panel B shows results for a change in mayors during an electoral term, when the new mayor is from the same party.

Interestingly, we find a convincing indication in panel A that "throwing the rascals out" could be a rather effective strategy in curbing the corrupt practices of politically aligned municipalities, but only if the new mayor comes from a different party. In turn, simply changing mayors seems to be an ineffective way of reducing local level corruption, as indicated in panel B. These results bear an important relation to a notable strain of literature starting with Olson (1982), and more recently Holcombe (2018), where it is argued that some degree of political instability might actually be beneficial in an economic-institutional sense, making it comparatively more difficult for corruption, rent-seeking, and special interests to dominate a political system. Of course, the success of such a removal strategy at the local level will crucially depend on whether the necessary political agreements can be reached to oust corrupt mayors and their parties from power.

\subsection{Robustness and research design validity}

\subsubsection{Robustness checks}

All of the main findings are robust to a variety of alternative sample selection criteria and a series of robustness checks. These are detailed in Appendix B of ESM, while this section provides a brief summary of the most relevant points, further demonstrating the validity of our research design.

First, we show robustness checks with respect to alternative estimation strategies: Appendix B.1 of ESM employs a "close-race" regression discontinuity design (RDD) in the spirit of Brollo and Nannicini (2012), where we compare municipalities in which aligned candidates barely won the elections to those in which they barely lost, following the procedure employed in Curto-Grau et al. (2018). Moreover, Appendix B.2 of ESM employs control variables to make treatment and outcome independent through matching techniques. Our findings prove robust to both strategies. ${ }^{21}$

In addition, we check the robustness of (i) our treatment variable definition in Appendix B.3 of ESM and (ii) of the control group in Appendix B.4 of ESM, employing different techniques. Findings show that our results are also robust to using as treatment "coalition alignment," to using additionally other possible forms of alignment (i.e., local-national, or regional-national), and also to changing the definition of the control group.

\footnotetext{
${ }^{21}$ Ideally, we would observe corruption when a municipality is treated $\left(Y_{1_{i j t}}\right)$, and when the same municipality is not treated $\left(Y_{0_{i j t}}\right)$. In this case, one could average the difference between $Y_{1_{i j t}}$ and $Y_{0_{i j t}}$ across all municipalities to obtain a measure of the average impact of the treatment. However, this ideal experiment is almost never available in observational data. Given that randomization is not possible either, we rely on the matching estimator to construct the correct sample counterpart for the missing information on the treated outcomes had they not been treated. Ideally, the only remaining difference between the two groups is the alignment status when employing this strategy.
} 
Another potential limitation of our estimates is the inclusion of municipalities ruled by local parties, because, by definition, they are always non-aligned. As a consequence, one may be concerned that the alignment effect is not well captured if municipalities ruled by local parties are systematically different from aligned ones, for instance, in terms of population size. We address this issue in Appendix B.5 of ESM, where we re-estimate Eq. (1) in a sub-sample of municipalities, excluding those ruled by local parties. In addition, we further restrict our sample by keeping only those municipalities ruled by the two main parties in the country, PP and PSOE, to avoid potential alignment effects from regional parties. In both sub-samples, the impact on corruption is actually slightly stronger.

The main regression models were further re-estimated, excluding the four regions with different electoral calendars, namely Andalucía, Catalonia, Galicia, and the Basque Country. Appendix B.6 of ESM shows that our results are not driven by municipalities located in these regions. Furthermore, we exclude either one region or one source of political corruption, highlighting in Appendix B.7 of ESM that findings are neither driven by a subset of municipalities within the same region, nor a particular source of corruption. Finally, Appendix B.8 of ESM excludes all corruption cases for which there is no corresponding judicial process. We do so to exclude the possibility that politically motivated accusations of corruption drive our results, finding this not to be the case.

\subsubsection{Research design validity}

In our model, the effect on local corruption of municipality $i$ being politically aligned is actually calculated via the difference for this same municipality being aligned, and non-aligned:

$$
\beta=\operatorname{Corr}_{i j t}^{T}-\operatorname{Corr}_{i j t}^{N T},
$$

where $\beta$ denotes the municipality-specific treatment effect, $\operatorname{Corr}_{i t}^{T}$ denotes the outcome in the treated group of municipalities, if aligned; and $\operatorname{Corr}_{i t}^{N T}$ denotes the outcome in the treated group of municipalities, had they not been aligned (Blundell and Costa Dias 2009).

Therefore, a necessary assumption to identify the effect of interest, $\beta$, is that selection into treatment is independent of $\epsilon_{i t}$, i.e., alignment is only correlated with the constant $\alpha_{i}$. However, one could think of many omitted variables that are perhaps correlated with both alignment and corruption, potentially invalidating this assumption. Although not directly testable, because the alignment status is obviously not the same in both groups of municipalities, we can nonetheless implement several tests to confirm the validity of our identification strategy.

First, we perform a sensitivity analysis by estimating a falsification test. Given that our empirical strategy is equivalent to a difference-in-differences (DiD) methodology, the level of corruption should follow the same trend in aligned and non-aligned municipalities. Taking advantage of the panel structure of our data, a "fake" treatment group — future alignment—is constructed to this end. Controlling for alignment 
in the present, any estimate on future alignment that is different from 0 would therefore provide evidence against the assumption that there are no time varying omitted factors. $^{22}$

Table 6 shows estimates, where the models and table structure is akin to those presented in Table 2. As can be observed, estimates for future alignment are always close to zero and insignificant, thus offering rather robust support for the validity of our research design, suggesting also that the common trend assumption is not violated. ${ }^{23}$

Second, we exploit changes in alignment by coding an additional electoral cycle preceding our data, namely the period between 1995 and 1999. Employing a DiD strategy, we then compare municipalities that experienced alignment for the first time to those that never experienced it during the entire period under observation-i.e. 1995-1999, 1999-2003, and 2003-2007 in the case of the 2007 elections; 1995-1999 and 1999-2003 in the case of the 2003 elections; and 1995-1999 in the case of the 1999 elections. To this end, we exclude all municipalities that experience alignment in the past. Specifically, we estimate the following model:

$$
\operatorname{Corr}_{i t}=\alpha_{i}+\gamma_{t}+\beta F A_{i t}+X_{i t}^{\prime} \delta+\epsilon_{i t}
$$

where $F A_{i t}$ is a dummy equal to one if the municipality is aligned for the first time. In this context, the parameter of interest in Eq. (4) captures the effect on corruption of local governments experiencing alignment for the first time, to those that are always non-aligned.

Table 7 shows DiD estimates from Eq. (4), with a very similar structure to the one presented in Table 2. ${ }^{24}$ Findings show that municipalities experiencing alignment for the first time are significantly more corrupt than those that never experience political alignment in our data, further suggesting that time varying unobserved factors do not play a significant role in explaining the political corruption of local governments in Spain.

\section{Discussion and conclusions}

Endemic corruption at the local level is a widely recognized problem in Spanish politics, and studying the mechanisms through which upper-tier levels of government can potentially influence such practices is key to understanding the role that political

\footnotetext{
22 The RDD robustness check presented in Appendix B.1 of ESM actually connects rather well with this idea, particularly regarding the "ideal" counterfactual group. If we find a significant effect when only employing municipalities close to the electoral threshold determining the alignment status it is because the variation in alignment is not driven by other observable determinants.

23 The evolution of corruption trends for treated and control municipalities further suggests no differences. Result are not reported but available upon request.

24 Note that, due to the large amount of observations dropped when creating both groups, estimations include all municipalities above 250 inhabitants. This threshold is chosen to guarantee that all local governments observed are elected via the same electoral system. Municipalities below 250 inhabitants follow an open list plurality-at-large system, where voters can choose individual candidates from the same, or different party-lists (Sanz 2017). Correspondingly, all controls that are only available for municipalities above 1000 inhabitants are dropped.
} 


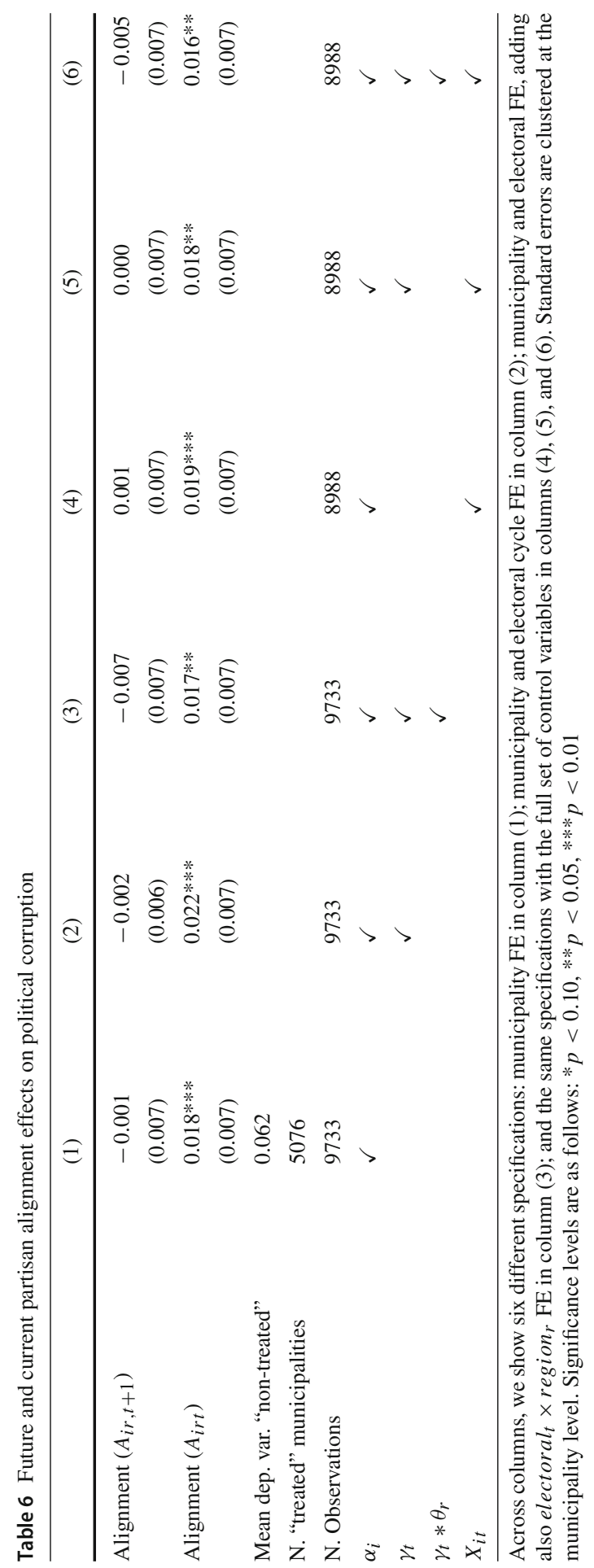




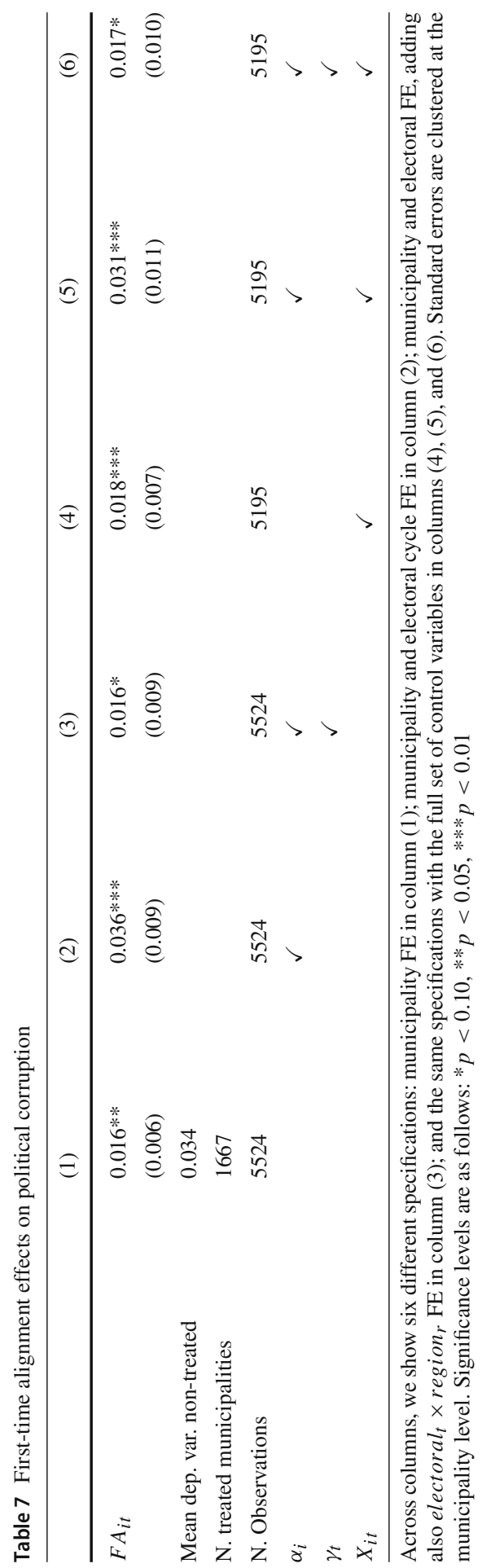


institutions play in its emergence. In an effort to expose an under-explored determinant, this paper investigates the impact of local and regional partisan alignment in fomenting local government corruption, employing systematic evidence from Spanish municipalities. To the best of our knowledge, this paper is the first to do so empirically.

Findings show aligned municipalities to be more corrupt than non-aligned ones, an effect that may be partially induced by absolute majorities at both levels of government, and also by higher capital transfers. Regarding the latter, previous literature has already suggested the allocation of additional transfers to politically aligned municipalities in Spain (Solé-Ollé and Sorribas-Navarro 2008; Curto-Grau et al. 2018), where we add the important notion that it would also increase local level corruption as an important by-product. Mechanisms could either be a reduced monitoring of aligned local governments, or if regional governments are able to influence the judiciary so that the probability of detection is lower. In the second case, our estimates would actually represent a lower bound for the effect of partisan alignment on political corruption. Interestingly, this idea is in line with our finding that absolute majorities at the local level seem to play a much less important role than absolute majorities at the regional level.

Conversely, it should be taken into account that our local corruption data are based on news reports of such practices at the municipal level. If a substantial number of these media reports are legally unfounded, estimates may effectively represent an upper bound for the effect of partisan alignment on political corruption. Notwithstanding, previous research for Spain with similar data has not found any evidence of such an inflationary effect (Costas-Pérez et al. 2012), nor do our robustness checks in Appendix B.8 of ESM suggest it to be present.

On a positive note, we find that "throwing the rascals out" could be an effective strategy in curbing the corrupt practices of politically aligned municipalities, but only if new mayors also come from different parties. In that context, it has been argued previously that a certain degree of political instability might actually be beneficial in an economic-institutional sense, making it comparatively more difficult for corruption, rent-seeking, and special interests to dominate a political system (Olson 1982; Holcombe 2018). Empirical support for these ideas comes from several cross-country studies (Berggren et al. 2012, 2015), but to date only tentative evidence exists for such an effect at the local level (Britto and Fiorin 2020). This could be a fruitful extension for future enquiries into the topic. Of course, the success of a political replacement strategy in curbing local level corruption will crucially depend on whether the necessary political agreements can be reached to remove corrupt mayors and their parties from power. Here, the design of policy reforms to facilitate local government accountability in Spain would be highly recommendable. Following our results, (i) making voters better informed through external audits of local governments (Ferraz and Finan 2008) and (ii) limiting the discretionary power of regional governments with an absolute majority, especially when allocating capital transfers, could potentially be effective measures in the quest to reduce political corruption at the Spanish municipal level.

Supplementary Information The online version contains supplementary material available at https://doi. org/10.1007/s13209-021-00228-6. 
Funding Financial support from the Spanish Ministerio de Economía y Competitividad (ECO2012-34928) is gratefully acknowledged.

\section{Compliance with ethical standards}

Conflict of interest The authors declare that they have no conflict of interest regarding this research.

Human and animal rights This article does not contain any studies with human participants or animals performed by any of the authors.

Open Access This article is licensed under a Creative Commons Attribution 4.0 International License, which permits use, sharing, adaptation, distribution and reproduction in any medium or format, as long as you give appropriate credit to the original author(s) and the source, provide a link to the Creative Commons licence, and indicate if changes were made. The images or other third party material in this article are included in the article's Creative Commons licence, unless indicated otherwise in a credit line to the material. If material is not included in the article's Creative Commons licence and your intended use is not permitted by statutory regulation or exceeds the permitted use, you will need to obtain permission directly from the copyright holder. To view a copy of this licence, visit http://creativecommons.org/licenses/by/4.0/.

\section{References}

AA.PP., M. (2008) Local Government in Spain. Country study, Ministry of Public Administration, Direccion General de cooperacion local

Albornoz F, Cabrales A (2013) Decentralization, political competition and corruption. J Dev Econ 105(C):103-111

Alternativas F (2007) Urbanismo y Democracia. Alternativas para Evitar la Corrupción http://www. falternativas.org/laboratorio/documentos/documentos-detrabajo/informe-de-la-democracia-2008la-estrategia-de-la-crispacion-derrota-pero-no-fracaso

Amundsen I (1999) Political corruption: an introduction to the issues. CMI working paper, Chr. Michelsen Institute

Anderson CJ, Tverdova YV (2003) Corruption, political allegiances, and attitudes toward government in contemporary democracies. Am J Polit Sci 47(1):91-109

Artés J, Jurado I (2018) Government fragmentation and fiscal deficits: a regression discontinuity approach. Public Choice 175(3):367-391

Arulampalam W, Dasgupta S, Dhillon A, Dutta B (2009) Electoral goals and center-state transfers: a theoretical model and empirical evidence from India. J Dev Econ 88(1):103-119

Berggren N, Bergh A, Bjørnskov C (2012) The growth effects of institutional instability. J Inst Econ $8(2): 187-224$

Berggren N, Bergh A, Bjørnskov C (2015) What matters for growth in Europe? Institutions versus policies, quality versus instability. J Econ Policy Reform 18(1):69-88

Blundell R, Costa Dias M (2009) Alternative approaches to evaluation in empirical microeconomics. J Human Resources 44(3):565-640

Bowler S, Karp J (2004) Politicians, scandals and trust in government. Polit Behav 26(3):271-287

Bracco E, Lockwood B, Porcelli F, Redoano M (2015) Intergovernmental grants as signals and the alignment effect: theory and evidence. J Public Econ 123:78-91

Britto DG, Fiorin S (2020) Corruption and legislature size: evidence from Brazil. Eur J Polit Econ 65:101940

Brollo F, Nannicini T (2012) Tying your enemy's hands in close races: the politics of federal transfers in Brazil. Am Polit Sci Rev 106:742-761

Busso M, DiNardo J, McCrary J (2014) New evidence on the finite sample properties of propensity score reweighting and matching estimators. Rev Econ Stat 96(5):885-897

Caliendo M, Kopeinig S (2008) Some practical guidance for the implementation of propensity score matching. J Econ Surv 22(1):31-72 
Calonico S, Cattaneo MD, Titiunik R (2014) Robust data-driven inference in the regression-discontinuity design. Stata J 14(4):909-946

Caplan B (2011) The myth of the rational voter: why democracies choose bad policies-new edition. Princeton University Press, Princeton

Carozzi F, Repetto L (2016) Sending the pork home: birth town bias in transfers to Italian municipalities. J Public Econ 134:42-52

Case A (2001) Election goals and income redistribution: recent evidence from Albania. Eur Econ Rev 45(3):405-423

Costas-Pérez E, Solé-Ollé A, Sorribas-Navarro P (2012) Corruption scandals, voter information and accountability. Eur J Polit Econ 28(4):469-484

Curto-Grau M, Solé-Ollé A, Sorribas-Navarro P (2018) Does electoral competition curb party favoritism? Am Econ J Appl Econ 10(4):378-407

de Jong E, Bogmans C (2011) Does corruption discourage international trade? Eur J Polit Econ 27(2):385398

Dehejia RH, Wahba S (2002) Propensity score-matching methods for nonexperimental causal studies. Rev Econ Stat 84(1):151-161

Delgado I (2010) Elecciones Municipales en España. Dimensiones Analíticas y Aspectos Distintivos de Ocho Procesos Electorales (1979-2007). Política y Sociedad 47(3)

Dell'Anno R, Teobaldelli D (2015) Keeping both corruption and the shadow economy in check: the role of decentralization. Int Tax Public Finance 22(1):1-40

Dey S, Sen K (2016) Is Partisan Alignment Electorally Rewarding? Evidence from Village Council Elections in India. IZA Discussion Papers 9994, Institute for the Study of Labor (IZA)

Dimant E, Tosato G (2018) Causes and effects of corruption: what has past decade's empirical research taught us? A survey. J Econ Surv 32(2):335-356

El Mundo (2006). Ladrillo a ladrillo. In https://www.elmundo.es. El Mundo

Erlingsson GO, Bergh A, Sjölin M (2008) Public corruption in Swedish municipalities-Trouble looming on the horizon? Local Gov Stud 34(5):595-608

Fabre B (2014) Political connections and alignment: evidence from intergovernmental grants in France. Technical report, Paris School of Economics mimeo

Fan CS, Lin C, Treisman D (2009) Political decentralization and corruption: evidence from around the world. J Public Econ 93(1-2):14-34

Fernández-Vázquez P, Barberá P, Rivero G (2016) Rooting out corruption or rooting for corruption? The heterogeneous electoral consequences of scandals. Polit Sci Res Methods 4(2):379-397

Ferraz C, Finan F (2008) Exposing corrupt politicians: the effects of Brazil's publicly released audits on electoral outcomes. Q J Econ 123(2):703-745

Ferraz C, Finan F (2011) Electoral accountability and corruption: evidence from the audits of local governments. Am Econ Rev 101(4):1274-1311

Fisman R, Gatti R (2002) Decentralization and corruption: evidence across countries. J Public Econ $83(3): 325-345$

Fitzpatrick TM (2007) A taxonomy of corruption. Journal Studia Universitatis Babes-Bolyai Negotia, Babes-Bolyai University, Faculty of Business

Gerring J, Thacker SC (2004) Political institutions and corruption: the role of unitarism and parliamentarism. Br J Polit Sci 34:295-330

Greene W (2004) The behaviour of the maximum likelihood estimator of limited dependent variable models in the presence of fixed effects. Econom J 7(1):98-119

Gutmann J, Lucas V (2018) Private-sector corruption: measurement and cultural origins. Soc Indic Res 138(2):747-770

Hahn J, Todd P, Van der Klaauw W (2001) Identification and estimation of treatment effects with a regressiondiscontinuity design. Econometrica 69(1):201-09

Holcombe RG (2013) Crony capitalism: by-product of big government. Indep Rev 17(4):541-559

Holcombe RG (2018) Political capitalism: how political influence is made and maintained. Cambridge University Press, Cambridge

Imbens G, Kalyanaraman K (2011) Optimal bandwidth choice for the regression discontinuity estimator. Rev Econ Stud 79(3):933-959

Imbens G, Lemieux T (2008) Regression discontinuity designs: a guide to practice. J Econom 142(2):615635 
Jerez Darias L. M, Martín Martín V. O, Pérez González R (2012) Aproximación a una Geografía de la Corrupción Urbanística en España. ERIA Revista Cuatrimestral de Geografía 1(87):5-18

Jiménez JL, García C (2018) Does local public corruption generate partisan effects on polls? Crime Law Soc Change 69(1):3-23

Jiménez JL, Garcí C, Mendez C (2013) How worried should national parties be about local corruption? Wp 01/2013. University of Barcelona, Cátedra Pasqual Maragall

Kaufmann D, Kraay A, Mastruzzi M (2004) Governance matters III: governance indicators for 1996, 1998, 2000, and 2002. World Bank Econ Rev 18(2):253-287

Kaufmann D, Kraay A Mastruzzi M (2009) Governance matters VIII: aggregate and individual governance indicators 1996-2008. Policy Research Working Paper Series 4978, The World Bank

Knack S (2006) Measuring corruption in eastern Europe and central asia: a critique of the cross-country indicators. The World Bank

Larcinese V, Rizzo L, Testa C (2006) Allocating the US federal budget to the states: the impact of the president. J Polit 68(2):447-456

Lee DS, Lemieux T (2010) Regression discontinuity designs in economics. J Econ Lit 48(2):281-355

Levitt SD, Snyder JM Jr (1995) Political parties and the distribution of federal outlays. Am J Polit Sci 39(4):958-980

Manzetti L, Wilson CJ (2007) Why do corrupt governments maintain public support? Comp Polit Stud 40(8):949-970

Mauro P (1995) Corruption and growth. Q J Econ 110(3):681-712

McCrary J (2008) Manipulation of the running variable in the regression discontinuity design: a density test. J Econom 142(2):698-714

Mendez F, Sepulveda F (2006) Corruption, growth and political regimes: cross country evidence. Eur J Polit Econ 22(1):82-98

Migueis M (2013) The effect of political alignment on transfers to Portuguese municipalities. Econom Polit 25(1):110-133

Miller AH (1999) Sex, politics, and public opinion: what political scientists really learned from the ClintonLewinsky scandal. PS Polit Sci Polit 32:721-729

OECD (2013) What are bribery and corruption? OECD Publishing, Paris, Bribery and Corruption Awareness Handbook for Tax Examiners and Tax Auditors

Olson M (1982) The rise and decline of nations: economic growth, stagflation, and social rigidities. Yale University Press, London

Pellegrini L, Gerlagh R (2008) Causes of corruption: a survey of cross-country analyses and extended results. Econ Gov 9(3):245-263

Perspectives E (1998) Corruption: an impediment to development, vol 3. Electronic Journal of the U.S. Information Agency

Reed SR (1999) Punishing corruption: the response of the Japanese Electorate to Scandals. Political Psychology in Japan, pp 131-148

Saiz A, Simonsohn U (2013) Proxying for unobservable variables with internet document-frequency. J Eur Econ Assoc Eur Econ Assoc 11(1):137-165

Sanz C (2017) The effect of electoral systems on voter turnout: evidence from a natural experiment. Polit Sci Res Methods 5(4):689-710

Sanz C, Solé Ollé A Sorribas P (2020) Betrayed by the elites: how corruption amplifies the political effects of recessions. IEB Working Paper 2020/02

Sanz Cazorla A (2007) La Escisión de Voto en la Competición Electoral multinivel de La Rioja: Elecciones Municipales y Autómicas, 1983-2007. Anuario Jurídico de La Rioja 1(12):91-117

Solé-Ollé A, Sorribas-Navarro P (2008) The effects of partisan alignment on the allocation of intergovernmental transfers. Differences-in-differences estimates for Spain. J Public Econ 92(12):2302-2319

Solé-Ollé A, Sorribas-Navarro P (2018) Trust no more? On the lasting effects of corruption scandals. Eur J Polit Econ 55:185-203

Solé-Ollé A, Viladecans-Marsal E (2013) Do political parties matter for local land use policies? J Urban Econ 78(C):42-56

Villalonga JR (2018) Fiscal centralization: a remedy for corruption? SERIEs 9(4):457-474

Warren ME (2004) What does corruption mean in a democracy? Am J Polit Sci 48(2):328-343

Wei S-J (2000) How taxing is corruption on international investors? Rev Econ Stat 82(1):1-11 
World Economic Forum (2008) Clean business is good business-the business case against corruption. International Chamber of Commerce, Transparency International, the United Nations Global Compact and the World Economic Forum

Publisher's Note Springer Nature remains neutral with regard to jurisdictional claims in published maps and institutional affiliations. 